UDC 340.15

DOI 10.32755/sjcriminal.2020.02.103

Zozulia Ye. V.,

Doctor of Sciences (Law), Professor, Professor of the Department of

General-legal disciplines, Donetsk Law Institute of Ministry of Internal Affairs of Ukraine, Mariupol, Ukraine ORCID: 0000-0002-8114-1133;

Hanzha Ya. K.,

officer,

Academy of the State Penitentiary Service, Chernihiv, Ukraine

\title{
UKRAINE AS A UNITARY STATE
}

The article analyzes the concept of a unitary state, considers decentralization in unitary states, and studies the views of various scientists on the processes of decentralization in unitary states. The most optimal form of government for Ukraine is determined to be a unitary republic with an expanded list of delegated powers to the regions.

Key words: decentralization, deconcentration, devolution, delegation, unitarity, unitary state.

Target setting. The Constitution of Ukraine contains special sections devoted to the territorial system, which develop the constitutional principle of unitarism, which is the basic value of the constitutional order of our state. Today, the vast majority of the world's sovereign states, especially European ones, are unitary. Modern Ukraine, like any other state in the world, is not a homogeneous nation-state entity, but its unitarity is indisputable.

The Ukrainian state has historically developed as a unitary entity, and therefore for Ukraine the unitary state system is more natural and historically formed. The independence of local selfgovernment should be expanded through further decentralization and democratization in the exercise of state power. We need to build a modern Ukraine with a modern legal system, based on best practices, but not trying to copy even the best world models, remembering that throughout the state, except for the Autonomous Republic of Crimea and Sevastopol, ethnic Ukrainians make up the majority. Thus, for our state, the optimal form of government is a unitary decentralized state with the recognition and guarantee of the rights of territorial communities as the primary subjects of local self-government. 
Actual scientific researches and issues analysis. Among the most important scientific studies on the problems of decentralization and unitarism should be mentioned the works of such famous researchers and scientists as O. M. Boryslavska, P. V. Vorona, V. D. Volkov, I. B. Zaverukha, N. V. Kaminska, Yu. V. Kovbasiuk, L. A. Pustovoit, O. P. Skorokhod, A. M. Shkolyk and others.

A number of studies on the organization of unitarity in the context of decentralization have been carried out by domestic scientists such as A. Tkachuk, V. Averianov, S. Romaniuk, V. Ponomariov, S. Sakhanenko, M. Derkach.

The purpose of the article is to analyze the unitarity of modern Ukraine and the prospects for the development of Ukraine as a unitary-decentralized state.

The statement of basic materials. A form of government is unitarity in which administrative-territorial units do not have the status of state formation. In a unitary state there are single for the whole country the highest bodies of state power, the legal system, the constitution, the armed forces.

The etymological dictionary of the Ukrainian language defines that "unitary - the only one that forms a single whole", and from the French means "unitaire" - "the same" associated with the Latin unitas "unity, a single whole", formed from the Latvian ūnus "one" [1, p. 36].

A clear definition of the term "unitary stat" is given by the encyclopedic dictionary of public administration, according to which a unitary state is the only centralized state, not divided into self-governing units. As a form of government, it is characterized by its features:

- single territory (there is an administrative division, but administrative units do not have political independence, although some may be granted the status of autonomy (self-government) national, territorial, cultural);

- a single constitution that applies throughout the country without any restrictions;

- a single system of supreme bodies of state power - the head of state, parliament, government, judiciary, whose jurisdiction extends to the entire territory of the country;

- a single system of law and a judicial system (including a single citizenship); 
- a single state budget, financial, tax and other systems.

Unitarity involves the centralization of the entire organizational structure of public administration, direct or indirect control over local authorities and local governments. At the same time, most modern democracies have elected local governments, to which the state delegates part of its functions as collection of local taxes, landscaping, construction, development of education, health care, etc. $[2$, p. 160$]$.

Thus, a unitary state does not consist of state formations, but of administrative-territorial units, the legal status of which is determined by the central government and is enshrined in the basic law and the constitution. The unitary nature of the existing states means that their territory is inextricably linked, marked by internal unity and has no signs of statehood, as is typical of the constituent parts of federal states $[3$, p. 88$]$.

Centralized unitary countries are characterized by the fact that management at all lower territorial levels is carried out by an administration appointed by the highest executive bodies of a state government.

Relatively decentralized unitary states are characterized by a combination of direct local government with local self-government: at the highest (region) and/or middle (district) subnational territorial levels, executive bodies of general competence and municipal bodies function simultaneously.

Decentralized unitary states are characterized by the fact that local authorities are formed independently of the central government (elected by the population, etc.) and have significant powers in resolving local issues in a certain territory.

Today, according to the Constitution, Ukraine is a unitary state, consisting of 24 regions, two cities of national importance - Kyiv and Sevastopol - and the Autonomous Republic of Crimea (the last two entities are temporarily occupied by the Russian Federation). The unitary status of Ukraine is enshrined in Article 2 of Section 1 of the Constitution of Ukraine [4].

The territorial structure of Ukraine is based on the principles of unity and integrity of the state territory, a combination of decentralization and centralization of state power; balance and socio- 
economic development of the regions, taking into account their historical, economic, environmental, geographical and demographic characteristics, ethnic and cultural traditions.

The unitarity of a state, its integrity and inviolability cannot be considered in isolation, because sovereignty and territorial integrity are a key to the existence of any state, as they form the basis without which it cannot function. Their guarantee and provision are one of the main tasks in the field of national security of any state.

The Constitution of Ukraine describes the unitary system of Ukraine in a special section "Territorial system of Ukraine", which defines its principles, including unity and integrity of state territory, a combination of centralization and decentralization in the exercise of state power, its balance and socio-economic development of regions, considering their historical, economic, environmental, geographical and demographic characteristics, also ethnic and cultural traditions. The principle of unitarity of the territorial system is also defined by the implicit norms devoted to territorial integrity, principles and mechanisms of realization of the public power and public management. The unitary system of Ukraine is characterized by an administrative-territorial system, the system of which consists of the Autonomous Republic of Crimea, regions, districts, cities, districts in cities, towns and villages. The administrative-territorial system is a territorial and administrative organization of the state both inside and outside, which is the basis for the public services to the population and the management of public affairs at the central, regional and local levels. There is also the principle of unitarity of the territorial system, which is defined by the implicit norms devoted to territorial integrity, principles and mechanisms of realization of the public power and public management.

In this regard, Nadutyi A.V. notes "the presence of its own territory is an integral feature of statehood, and indivisibility and integrity - the essential characteristics of the territory of a sovereign state. The principle of integrity of the state territory is aimed at ensuring the inseparability of the constitutive element of the state that is the territory" [5, p. 30].

Undoubtedly, no state can function without sovereignty and territorial integrity since their guarantee and provision are one of the 
main tasks in the field of ensuring the national security of any state, its constitutional order. We agree that the integrity and inviolability of the territory of the state are its defining legal characteristics and require appropriate guarantees and special legal protection. Given the political and social challenges of today, the urgency of this problem for the Ukrainian state is constantly growing.

The same opinion has O. O. Iliashko, who points out that ensuring the territorial integrity of Ukraine is an integral part of the legal mechanism for ensuring the constitutional order and sovereignty of the state. Such a mechanism consists of constitutional and legal guarantees of unity, integrity and inviolability of the territory of Ukraine, as well as a legitimate constitutionally regulated procedure for changing the state border [6, p. 38].

Thus, the unitary state of its integrity and inviolability should be considered as one integral phenomenon, because inviolability is a principle of public international law, according to which the territory of a state is inviolable from encroachment by other states through force, which violates the integrity of a state and if there is no integral territory, then it is impossible to build a system.

Thus, the state with a unitary form of government ensures state integrity and includes certain territorial entities endowed with special powers of a non-state nature. That is, the composition of a unitary state may include autonomies, and in addition, the unitary state may well consist of such autonomies, the main thing is that these territorial entities do not have the status of a state entity.

Thus, the new definition of a unitary state can be offered. Unitary is the state, the territory of which is single, but is divided into administrative-territorial units (districts, regions), which are subordinate to the central authorities and do not have sovereign rights.

To further study the problems of unitarity of modern Ukraine and the prospects for the development of Ukraine as a unitarydecentralized state, it is necessary to define the concept of decentralization.

A large explanatory dictionary of the modern Ukrainian language interprets the "decentralization" concept as a system of government in which part of the functions of central government passes to local governments; abolition or weakening of centralization [7]. 
Thus, decentralization should be understood as the process of expanding and strengthening the rights and powers of administrativeterritorial units or lower bodies and organizations while narrowing the rights and powers of the center to optimize and improve the management of socially important affairs, the fullest realization of regional and local interests.

Nowadays scientists distinguish three main forms of decentralization - econcentration, devolution and delegation.

Deconcentration involves shifting administrative responsibilities from ministries and other central executive bodies to the regional and local administrative levels by establishing appropriate units of central executive bodies and transferring a number of decision-making powers.

The devolution aims to strengthen local authorities by delegating to them powers, responsibilities and resources to provide service delivery infrastructure, support the health and safety of citizens, shape and implement various policy areas at the local level.

By delegation, public authorities delegate the authority to organize the implementation of certain functions to semiautonomous from the central government institutions for regional planning and development agencies, state enterprises, as well as multi-purpose or specially created public authorities [8].

The opinion of Z. O. Siryk should be agreed, since he notes that "in Ukraine there is a use of the consolidation practice of local governments at the local and district levels to increase the efficiency of economic and industrial relations, which have historically developed, in particular, within industrial agglomerations. The creation of such administrative-territorial entities will significantly increase the level of resource provision of local government functions, and thus make them independent in addressing territorial development issues and, accordingly, reduce the amount of subventions and equalization subsidies from the state budget.

In modern conditions Ukraine sees the need to implement more widely the mechanism and tools to ensure cooperation and unification of village, settlement, city councils to address the issues of socio-economic development of territories. The legislative basis is created for this $[9$, p. 122]. 
Constitutional consolidation of the municipal dualism principles, which states the ability of local governments to address issues of local importance and to participate in the resolution of state affairs through the exercise of delegated powers. This will ensure the implementation of the provisions of the European Charter of Local Self-Government and the constitution of national traditions of local self-government, as well as provide an opportunity to combine the principles of decentralization of public power and subsidiarity in the functional-competent mechanism of local self-government [10].

Conclusions. Thus, the unitarity is manifested through the centralization of public administration, direct or indirect control over municipal authorities. Instead, most modern democracies have elected local governments to which the state has delegated some of its functions at the local level.

A unitary state is a single integral state, the territory of which is divided into administrative-territorial units that do not have the status of state entities and do not have sovereign rights. The process of decentralization of power in developed unitary countries was characterized by appropriate preconditions, in particular: social, economic and political. Decentralization has its own development trends, in particular, the democratization of domestic relations, increasing the responsibility of state power to the people.

The effectiveness of decentralization in unitary countries is manifested in the principle of building inter-budgetary relations, despite the tradition of existence in such states of the budget system built on the principle of budgetary unitarism, more optimal and effective should be considered the introduction of a system based on so-called "budget federalism", which is characterized by the delimitation of budgetary rights and powers in the field of formation and expenditure of budgetary funds between the state and local authorities.

For the proper implementation of its powers and functions by the central level of government should be created an appropriate control mechanism, the basis of which is judicial (constitutional supervision) and some special procedures (referendums, impeachments, dissolution of parliament, etc.). The most optimal variant of the form of government for Ukraine is a unitary republic with the expansion of powers delegated to the regions. 


\section{References}

1. Melnychuk, O. S. (2012), Etymological dictionary of the Ukrainian language, Scientific thought, Kyiv.

2. Kovbasiuk, Y. V., Troshchynskyi, V. P., Surmin, Y. P. (2010), Encyclopedic dictionary of public administration, NAPA, Kyiv.

3. Ponomariov, V. (2018), Features of decentralization of power in the unitary states of the world, Theoretical and applied issues of state formation, Issue 22, pp. 82-90.

4. Ukraine (1996), The Constitution of Ukraine: Law of Ukraine, available at: http://zakon4.rada.gov.ua/laws/show/96 (accessed 04.09.2020).

5. Nadutyi, A. V. (2016), "Territorial unity, integrity and inviolability: on the question of the relationship of concepts", Law and Security, Issue 1, pp. 29-34.

6. Iliashko, O. O. (2018), "Ensuring the territorial integrity and inviolability of Ukraine: national and international legal aspects", Scientific notes of Tavriia National University named after V.I. Vernadskyi. Series: Legal Sciences, Vol. 29 (68), Issue 3, pp. 33-39.

7. Busel, W. T. (2005), Large explanatory dictionary of the modern Ukrainian language, Perun, Irpen.

8. Romaniuk, S. A. (2018), Decentralization: theory and practice: monograph, NADU, Kyiv.

9. Sirik, Z. A. (2015), "Administrative and territorial structure of France: current experience for Ukraine", Regional economy, Issue 3, pp. 116-124.

10. The concept of amending the Constitution of Ukraine, available at: http://khpg.org/index.php?id=1372332292 (accessed 04.09.2020).

Зозуля С. В., доктор юридичних наук, професор, професор кафедри загальноправових дисциплін, Донецький юридичний інститут МВС України, м. Маріуполь, Україна ORCID: https://orcid.org/0000-0002-8114-1133;

Ганжа Я. К.,

слухачка 361-ої навчальної групи, Академія Державної пенітенціарної служби, м. Чернігів, Україна

\section{УКРАЇНА ЯК УНІТАРНА ДЕРЖАВА}

У статті проаналізовано поняття унітарності, розглянуто децентралізація в унітарних державах, вивчено погляди різних учених на прочеси децентралізачії в унітарних державах. Визначено, щчо найбільш оптимальнішим варіантом форми державного устрою для Украӥни є унітарна республіка 3 розширеним переліком делегованих повноважень регіонам. 
У Конституиії України містяться спеціальні розділи, присвячені територіальному устрою, які розвивають конституційний принции унітаризму, щчо є базовою ичінністю конституційного ладу нашої держави. Сьогодні переважна більшість суверенних держав світу, а особливо європейських, є унітарними. Сучасна Україна, як $i$ будь-яка інша держава світу, не є однорідним національно-державним утворенням, але її унітарність беззаперечна.

Украӥнська державна історично складалась як унітарне утворення, а тому для України більш природним та історично сформованим є саме унітарний державний устрій. Слід розширити самостійність місиевого самоврядування за рахунок подальшої децентралізаиї $i$ демократизачії у здійсненні державної влади. Треба будувати новітню Украӥну з сучасною правовою системою, орієнтуючись на передовий досвід, проте не намагаючись копіювати навіть найкращі світові зразки і пам'ятаючи, щуо на всій державній території, за винятком Автономної Республіки Крим та Севастополя, етнічні украӥниі складають більшість населення.

Визначено, щзо децентралізація має власні тенденції розвитку, зокрема, демократизація внутрішньодержавних відносин, підвищення відповідальності державної влади перед народом. Ефективність децентралізації в унітарних краӥнах виявлясться й у принципі побудови міжбюджетних відносин, тобто незважаючи на традииії існування в таких державах бюджетної системи, побудованої на принципі бюджетного унітаризму, більи оптимальним $і$ ефективним слід вважати запровадження системи, побудованої на принципі так званого "бюджетного федералізму», для якого характерним є розмежування бюджетних прав і повноважень у сфері формування та витрачання бюджетних коштів між державою та місиевими органами.

Доведено, щзо для належного здійснення ијентральним рівнем влади його повноважень $i$ функцій створено відповідний механізм контролю, основою якого є судовий (конституційний нагляд) та деякі спеціальні прочедури (референдуми, імпічменти, розпуск парламенту тощз). Найбільш оптимальнішим варіантом форми державного устрою для України є унітарна республіка з розширеним переліком делегованих повноважень регіонам.

Ключові слова: децентралізація, деконщентрація, деволючія, делегування, унітарність, унітарна держава. 